\title{
MATERNAL AND CHILD HEALTH HANDBOOK AS HEALTH PROMOTION TOOL FOR POSTPARTUM AND BREASTFEEDING MOTHERS: A SYSTEMATIC REVIEW
}

\author{
Rizki Amalia, Yunik Windarti
}

Universitas Nahdlatul Ulama Surabaya

\begin{abstract}
Background: The maternal and child health handbook is a tool used by all postpartum and breastfeeding mothers up to the child aged five years. In Indonesia, the maternal and child health services recorded separately in sheets/ cards with a high probability of being lost and scattered were integrated into a home-based record handbook in 1994. This study aimed to investigate the evidence of maternal and child health handbook as health promotion tool for postpartum and breastfeeding mothers.

Subjects and Method: A systematic review was conducted by searching from PubMed, Google Scholar, and Ichushi-Web. The keywords were maternal and child health handbook and health promotion. The related articles published between 1990 to 2020 were collected for this review. Twenty-eight articles were eligible for this review. The data were reported systematically.

Results: A total of 28 articles, consisting 3 review articles, 17 primary studies, 2 reports, 2 letters, 1 research note, and 3 proceedings, discussed the benefits of maternal and child health handbooks as a health promotion tool for postpartum and breastfeeding mothers.

Conclusion: Maternal and child health handbook is a good health promotion tool for postpartum and breastfeeding mothers.
\end{abstract}

Keywords: maternal and child health handbook, health promotion, postpartum, breastfeeding, mothers

\section{Correspondence:}

Rizki Amalia. Universitas Nahdlatul Ulama Surabaya. Jl. SMEA No 57 Wonokromo, Surabaya, East Java.Email: amalia24@unusa.ac.id. Mobile: +6285655581002.

\section{BACKGROUND}

The Maternal and Child Health (MCH) book is a very important tool used by almost every Indonesian parent. The MCH Handbook contains information on maternal health (pregnancy and childbirth) and child health (monitoring of growth and development, immunization and recording of children's health) as well as various information on how to main-tain and care for maternal and child health (JICA, 2015). The MCH handbook can des-cribe continuing care from pregnancy, childbirth, postpartum, and breastfeeding to children aged 6 years (Osaki et al., 2015).

Information in the KIA book can increase knowledge and understanding of $\mathrm{MCH}$ so that it can mobilize and empower people to live healthily, provide information about the risk of complications, how and where to get health services and increase community ac-cess to quality health services (Bhuiyan and Nakamura, 2008). Knowledge of postpartum and breastfeeding is important for early detection of complications after delivery and breastfeeding, which will help reduce AKI and IMR (Mahayati et al., 2014).

In Indonesia, $\mathrm{MCH}$ books have not been used optimally, as evidenced by the low awareness of mothers to read the messages contained in the MCH books. Sistentuki et al. (2014) stated that mothers who had good knowledge of the MCH handbook significant-

The 7th International Conference on Public Health Solo, Indonesia, November 18-19, 2020 |74 https://doi.org/10.26911/the7thicph-FP.03.15 
ly increase their compliance with the use of the $\mathrm{MCH}$ Handbook. Cadres also significantly influence the use of the MCH handbook even though their roles have not been carried out optimally, including not making home visits and unsure whether home visits, carry out the messages in the KIA book (Widagdo and Husodo, 2009). The government had decided to use the $\mathrm{MCH}$ Handbook to communicate and a medium for outreach for mothers and families and the juveniles regarding maternal and child health services. Besides, references services, packages (standards) of $\mathrm{MCH}$, nutri-tion, immunization, toddlers' growth, and de-velopment services are also delivered (MOH RI, 2004).

Data regarding postpartum health and breastfeeding around the world are limited. This study collected articles to review recent healthcare systems research to provide better maternal and child health in the future. This review article aimed to discuss maternal and child health, history, and benefits based on existing literature.

\section{SUBJECTS AND METHOD \\ 1. Study Design \\ A systematic review was conducted by searching electronic databases from PubMed, Google Scholar, and Ichushi-Web. The keywords were maternal and child health handbook and health promotion.}

\section{Inclusion and Exclusion Criteria}

The inclusion criteria in this study were inter-national journals related to maternal and child health books. The related articles published between 1990 to 2020 were collected for this review. Articles did not meet the eli-gibility criteria were excluded.
3. Operational Definition of Variable Maternal and child health books are books as a promotion of maternal and child health.

\section{Analysis Data}

The data were reported systematically using PRISMA flow chart.

\section{RESULTS}

Twenty-eight papers were obtained: 3 review articles, 17 original articles, 2 brief reports, 2 letters, 1 research note, and 3 proceedings. The summary sources were stated in Table 1.

\section{DISCUSSION}

Handbook on maternal and child health was published in Japan in 1945, and infant mortality was around 76 per 1000 live births, about two times higher than the IMR in the UK. The government of Japan formed a Maternal and Child handbook to publish together to support the maternal and child health service system.

Although the maternal and child health books had been completed at their respective destinations in Japan, Indonesia had started to use the $\mathrm{MCH}$ handbook and was trying to distribute to all maternal and child health service resources in Indonesia. This book was accompanied by several illustrations with lots of colorful pictures to ensure that illiterate parents easy understand the information. $\mathrm{MCH}$ books have an important role in reducing maternal and child health rates. This research was only conducted by collecting certain articles with limited research studies go directly to the land due to the Covid-19 pandemic. 


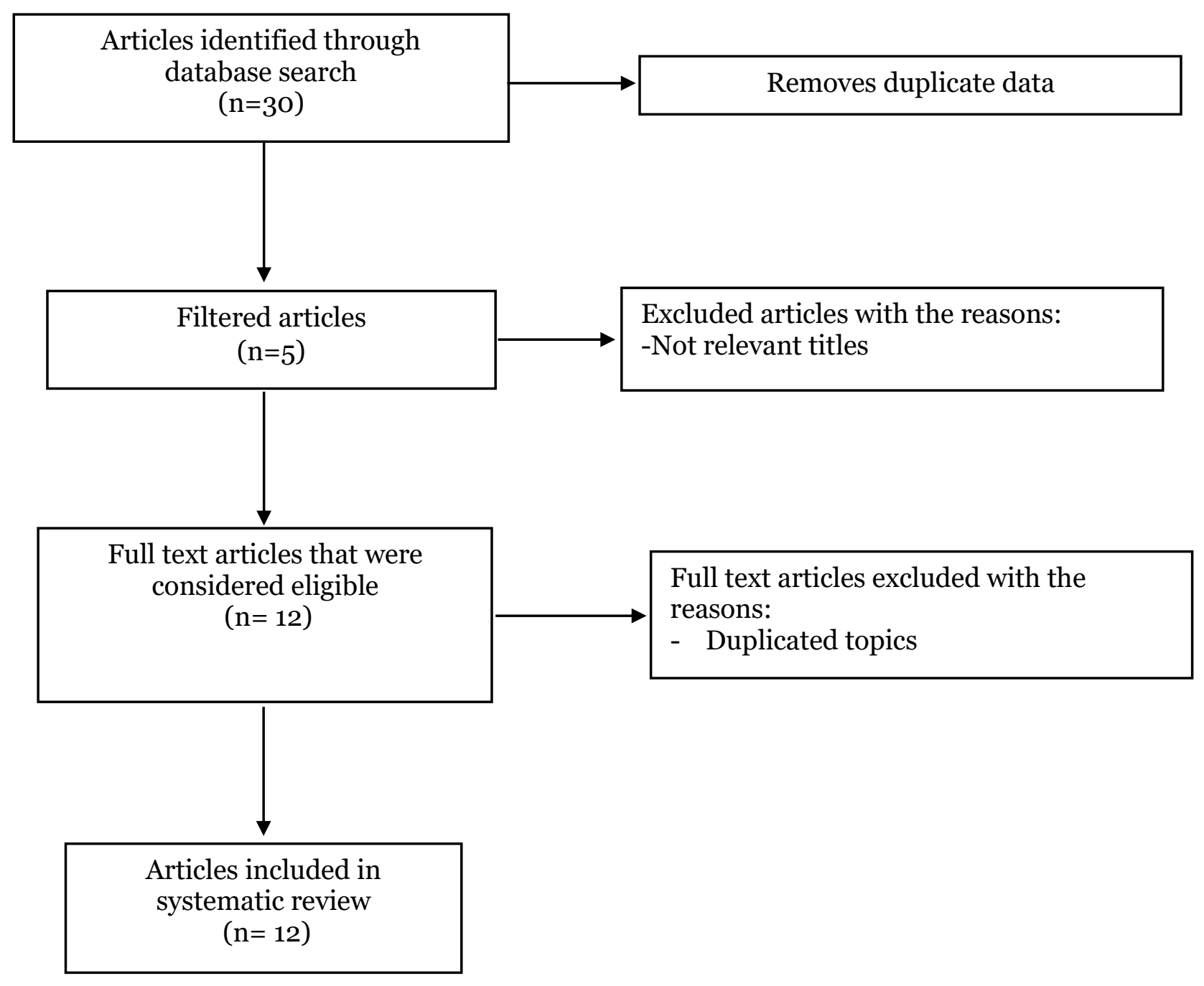

Figure 1. PRISMA flow Diagram

The 7th International Conference on Public Health Solo, Indonesia, November 18-19, 2020 |76 https://doi.org/10.26911/the7thicph-FP.03.15 
Table 1. Summary Sources

\begin{tabular}{|c|c|c|c|c|}
\hline No & $\begin{array}{c}\text { Authors } \\
\text { (Years) }\end{array}$ & Title & Type of Study & $\begin{array}{c}\text { Searching } \\
\text { tool }\end{array}$ \\
\hline 1. & Mamiya (1990) & $\begin{array}{l}\text { Japan's Maternal and Child } \\
\text { Health Handbook }\end{array}$ & Letter & $\begin{array}{l}\text { PubMed, } \\
\text { Google } \\
\text { scholar }\end{array}$ \\
\hline 2. & $\begin{array}{l}\text { Takayanagi et al. } \\
\text { (1993) }\end{array}$ & $\begin{array}{l}\text { The Role of the Maternal } \\
\text { and Child Health Handbook } \\
\text { system in reducing perina- } \\
\text { tal mortality in Japan }\end{array}$ & Review article & $\begin{array}{l}\text { PubMed, } \\
\text { Google } \\
\text { scholar }\end{array}$ \\
\hline 3. & Kunugi et al. (1996) & $\begin{array}{l}\text { Perinatal complications } \\
\text { and schizophrenia. Data } \\
\text { from the Maternal and } \\
\text { Child Health Handbook in } \\
\text { Japan }\end{array}$ & Original article & $\begin{array}{l}\text { PubMed, } \\
\text { Google } \\
\text { scholar }\end{array}$ \\
\hline 4. & Ohara et al. (2005) & $\begin{array}{l}\text { Obstetric complications in } \\
\text { siblings of Japanese schi- } \\
\text { zophrenics: data from the } \\
\text { Maternal and Child Health } \\
\text { Handbook }\end{array}$ & Original article & $\begin{array}{l}\text { PubMed, } \\
\text { Google } \\
\text { scholar }\end{array}$ \\
\hline 5 . & Toyama (2008) & $\begin{array}{l}\text { Maternal and Child Health } \\
\text { Handbook Program in } \\
\text { Japan }\end{array}$ & $\begin{array}{l}\text { Conference } \\
\text { proceedings }\end{array}$ & $\begin{array}{l}\text { PubMed, } \\
\text { Google } \\
\text { scholar }\end{array}$ \\
\hline 6. & Nagata (2008) & $\begin{array}{l}\text { The Maternal and Child } \\
\text { Healthcare Handbook in } \\
\text { Utah, USA }\end{array}$ & $\begin{array}{l}\text { Conference } \\
\text { proceedings }\end{array}$ & $\begin{array}{l}\text { PubMed, } \\
\text { Google } \\
\text { scholar }\end{array}$ \\
\hline 7 . & Osaki (2008) & $\begin{array}{l}\text { MCH Handbook and } \\
\text { International Collaboration }\end{array}$ & $\begin{array}{l}\text { Conference } \\
\text { proceedings }\end{array}$ & $\begin{array}{l}\text { PubMed, } \\
\text { Google } \\
\text { scholar }\end{array}$ \\
\hline 8. & Nakamura (2010) & $\begin{array}{l}\text { Maternal and Child Health } \\
\text { Handbook in Japan }\end{array}$ & Review article & $\begin{array}{l}\text { PubMed, } \\
\text { Google } \\
\text { scholar }\end{array}$ \\
\hline 9. & $\begin{array}{l}\text { Baequni et al. } \\
\text { 2012) }\end{array}$ & $\begin{array}{l}\text { Is maternal and child } \\
\text { health handbook effective? } \\
\text { Meta-analysis of the } \\
\text { effects of MCH Handbook } \\
\text { The Maternal and Child }\end{array}$ & Original article & $\begin{array}{l}\text { Ichu-Shi Web } \\
\text { and Google } \\
\text { Scholar }\end{array}$ \\
\hline 10. & Mori et al. (2015) & $\begin{array}{l}\text { Health (MCH) handbook } \\
\text { in Mongolia: a cluster- } \\
\text { randomized, controlled } \\
\text { trial }\end{array}$ & Original article & $\begin{array}{l}\text { PubMed, } \\
\text { Google } \\
\text { scholar }\end{array}$ \\
\hline
\end{tabular}


11. Kawakatsu et al. (2015)

12. (2015)
Effectiveness of and factors

related to possession of a mother and child health handbook: an analysis using propensity score matching.
Original article

PubMed, Google scholar
Effect of a maternal and child health handbook on maternal knowledge and behavior: a communitybased controlled trial in rural Cambodia

\author{
Original article $\quad \begin{aligned} & \text { PubMed } \\ & \text { Google }\end{aligned}$ \\ scholar
}

\section{REFERENCES}

Aoyama T, Tsushita K, Miyatake N, et al. (2013). Does cardiorespiratory fitness modify the association between birth weight and insulin resistance in adult life? PLoS One. 8: e73967. doi: 10.1371 / journal.pone.0073967

Baequni, Nakamura Y (2012). Is maternal and child health handbook effective? A metaanalysis of the effects of $\mathrm{MCH}$ Handbook. J Int Health. 27: 121-127. doi: 10.11197 / jaih.27.121.

Fujita Y, Kouda K, Nakamura H, Iki M (2013). Asso-ciation of rapid weight gain during early childhood with cardiovascular risk fac-tors in Japanese adolescents. J Epi-demiol. 23: 103-108. doi: 10.2188 / jea.JE20120107.

Kawakatsu Y, Sugishita T, Oruenjo K, et al.(2015). Effectiveness of and factors related to possession of a mother and child health handbook: an analysis using propensity score matching. Health Educ Res. 30: 935-946. doi: 10.1093 / her / cyvo48.

Kunugi H, Nanko S, Takei N, Saito K, Murray RM, Hirose T (1996). Perinatal complications and schizophrenia. Data from the Maternal and Child Health Hand- book in Japan. J Nerv Ment Dis. 184: 542-546.

Kouda K, Nakamura H, Fujita Y, Iki M (2012). Relationship between body mass index at age 3 years and body composition at age 11 years among Japanese children: the Shizuoka population-based study. J Epidemiol. 22: 411-416. doi: 10.2188 / jea.JE20110113.

Mamiya U. Japan's Maternal and Child Health Handbook (1990). Midwives Chron: 103: 314-315.

Leppert PC (1993). An analysis of the reasons for Japan's low infant mortality rate. J Nurse Midwifery. 1993; 38: 353-357.

Ministry of Health, Labor and Welfare (2014). About the Maternal and Child Health Handbook [in Japanese]. Retrieved from http: //www.niph. go.jp/soshiki-

/o7shougai/hatsuiku/index.files/koufu. pdf.

Ministry of Health, Labor and Welfare (2015). Pro-motion of becoming ICT in the medical care field [in Japanese]. Retrieved from http://www.kantei.go.jp/jp/singi/keizaisaisei/kadaibetu/ dai6 / siryou1.pdf.

Ministry of Internal Affairs and Communications. Comprehensive planning,

The 7th International Conference on Public Health Solo, Indonesia, November 18-19, 2020 |78

https://doi.org/10.26911/the7thicph-FP.03.15 
drafting and promotion of ICT policy.

Retrieved

from

http://www.soumu.go.jp/english-

/gisb/index.html.

Nagata M (2008). Baby: your baby program. paper presented at: the 6th international conference on Maternal and Child Health (MCH) Handbook; Tokyo, Japan. Retrieved from http://ir.library.osaka-u.ac.jp/dspace/bit- stream / 110-94/14054/3 / ProcMCH_day22.pdf

Nakamura Y. Maternal and Child Health Handbook in Japan. Japan Med AssocJ.2010; 53: 259-265

Ohara K, Tanabu S, Yoshida K, Sato Y, Shibuya H (2005). Obstetric complications in siblings of Japanese schizophrenics: data from the Maternal and Child Health Handbook. Prog Neuropsychopharmacol Biol Psychiatry. 29: 617-620. doi: 10.1016 / j.pnpbp.2005.01 .005 .

Osaki K (2008). MCH Handbook and international collaboration. Paper presented at: The 6th International Con-ference on Maternal and Child Health (MCH) Handbook; Tokyo, Japan. Retreived from http://ir.library.osaka-u.-ac.jp/ dspace / bitstream / 11094/14-054/3 / ProcMCH_day2-2.pdf.

Takayanagi K, Iwasaki S, Yoshinaka Y (1993). The Role of the Maternal and Child Health Handbook System in reducing perinatal mortality in Japan. Clin Perform Qual Health Care. 1993; 1: 2933.

Toyama N. Maternal and Child Health Handbook Program in Japan (2008). Paper present-ed at: The 6th International Conference on Maternal and Child Health (MCH) Handbook, Tokyo, Japan. Retreived from http: // ir.libra-ry.osaka-u.ac.jp/dspace/bitstream/11094/14054/3/ ProcMCH_day2-2.pdf. Yanagisawa S, Soyano A, Igarashi H, Ura M, Nakamura Y (2015). Effect of a maternal and child health handbook on maternal knowledge and behavior: a community-based controlled trial in rural Cambodia. Health Policy Plan. 30: 1184-1192. doi: 10.1093 / heapol / czu133. 